\title{
Developmental Changes and Sex Difference in Glucose- 6-Phosphate Dehydrogenase Activity of Bovine Oocytes and Embryos Fertilized in Vitro
}

\author{
Setsuo Iwasaki, Yasuo Shioya*, Yasunori MonjI**, \\ and Tatsuo Nakahara \\ NODAI Research Institute, Tokyo University of Agriculture, Setagaya-ku, Tokyo 156, \\ *National Institute of Animal Industry, Tsukuba Norindanchi, P. O. Box 5, \\ Ibaraki 305, Japan, **Department of Animal Science, Tokyo University \\ of Agriculture, Setagaya-ku, Tokyo 156, Japan
}

(Accepted for publication July 20, 1989)

\begin{abstract}
Summary. The developmental changes and sex difference in activity of glucose-6phosphate dehydrogenase (G-6-PDH) of bovine oocytes and early embryos derived from follicular oocytes fertilized in vitro were histochemically examined. Bovine embryos at two- to eight-cell stages were separated into two halves by pipetting after removal of zona pellucida by treating with $0.5 \%$ pronase. One half was assayed for G-6-PDH activity and the other was used to determine sex by chromosome analysis. There was no definite tendency in G-6-PDH activity from matured oocytes to the eight-cell embryos and no activity was observed at morulae stage. We found no sex difference in the G-6-PDH activity of bovine two- to eight-cell embryos derived from follicular oocytes. A high activity was observed in some embryos with four or six X-chromosomes.

KEY WORDS; G-6-PDH, BOVINE EMBRYO, SEX DIFFERENCE.
\end{abstract}

Jpn J Anim Reprod 35, 198-203, 1989

Lyon (1961) postulated that one of X-chromosomes was inactivated in early embryonic development in mammals. This hypothesis has been proved biochemically (Chapman and Shows, 1976) and cytogenetically (Takagi, 1974). Embryos with two X-chromosomes (XX) should show twice the activity of X-linked enzymes than embryos with one X-chromosome (XY or XO) (Monk, 1978). In fact, the distribution of $\alpha$-galactosidase $(\alpha$-Gal) activity (Adler et al., 1977) and of hypoxanthine guanine phosphoribosyl transferase (HGPRT) (Monk, 1978) was bimodal at the morulae stage of mouse embryos. However, $\mathrm{X}$ bimodal distribution for either G-6-PDH in pre-implantation mouse and rabbit embryos (Brinster, 1970) or phosphoglycerate kinase (PGK) in 6.5-day mouse embryos (Kozak and Quinn, 1975) had not been demonstrated.

Recently, sex determination of embryos by measurement of the $\mathrm{X}$-linked gene dosage has been reported successful in G-6-PDH (Williams, 1986) and HGPRT experiments (Epstein et al., 1978, Monk and Handyside, 1988). In domestic livestock species, little is known about sexing of embryos by measurement of the X-linked enzyme. G-6-PDH, $\alpha$-Gal, PGK and HGPRT are linked with the X-chromosome in cattle as well as man and the mouse (Shimizu et al., 1981). Accordingly, it may be possible to control the sex at the early embryo stage depending on the sex difference in the activities of these enzymes.

The authors clarified the developmental changes in G-6-PDH activity of bovine oocytes and embryos histochemically. Secondly, the sex difference of G-6-PDH activity of embryos was investigated. That is, the embryo was separated into two halves by treating with pronase; one half was used to assay the activity of G-6-PDH 
and the other was used to determine the sex by chromosome preparation.

\section{Materials and Methods}

Preparation of oocytes and two-to eight-cell bovine embryos

Bovine oocytes and embryos at various stages were prepared by maturation and fertilization in vitro using follicular oocytes as in the previous paper (Iwasaki et al., 1988) with minor modification in collection of follicular oocytes and the treatment of semen. For our experiments, we used two differing methods for collection of follicular oocytes. In Exp. 1, pooled oocytes collected singly from various ovaries were used. In Exp. 2, oocytes taken from multifollicled ovaries (60-80 follicles) were used separately.

Frozen ejaculated sperm from Japanese Black Cattle was used for in vitro fertilization in Exp. 1. The sperm was washed twice with caffeinesodium benzoate (Sigma) and the sperm concentration was adjusted to $25 \times 10^{6} / \mathrm{ml}$. The sperms were then treated with $0.1 \mu \mathrm{M}$ ionophore A23187 (Calbiochem-Berhring) for $1 \mathrm{~min}$, followed by incubation with $2 \mathrm{mg} / \mathrm{ml}$ of bovine serum albumin (BSA, crystalized and lyophylized, Sigma). Then matured oocytes were immediately incubated for $6 \mathrm{hr}$ with sperm treated with ionophore. In Exp. 2, frozen epididymal semen was washed with caffeine-sodium benzoate and the sperm concentration was adjusted to $20 \times 10^{6} / \mathrm{ml}$. It was incubated for $5 \mathrm{hr}$ without treatment with ionophore and then incubated with matured oocytes for $4 \mathrm{hr}$.

Finally, matured oocytes were obtained at 24 hr after culture. Sperm-penetrated oocytes and oocytes at pronuclei stage were obtained at $5 \mathrm{hr}$ or $18 \mathrm{hr}$ after insemination, respectively. Twoto eight-cell embryos were obtained at 4l-44 hr after insemination.

Removal of zona pellucida and separation of embryos

The embryos were treated with $0.5 \%$ Actinase E (Kaken Kagaku, Japan) in phosphate buffered saline (PBS) for 2-3 min. Then they were placed in PBS with $0.3 \% \mathrm{BSA}$ and the zona pellucida was removed by pipetting. The blastomeres were separated and placed in substrate mixture for assay of G-6-PDH activity or in TCM 199 medi- um containing $0.08 \mu \mathrm{g} / \mathrm{ml}$ vinblastin (Sigma) and podophyllotoxin (Aldorich) for 8-12 hr.

\section{Histochemical assay for G-6-PDH activity}

G-6-PDH activity of bovine oocytes and embryos was histochemically determined using the method of Niimura and Ishida (1977) with minor modification of the concentration of tris buffer and the reaction temperature. That is, the reaction was run in a $0.1 \mathrm{ml}$ reaction mixture containing the following components: $0.125 \mathrm{M}$ tris$\mathrm{HCl}$; $1.4 \mathrm{mM}$ D-glucose-6-phosphate disodium salt (Sigma); $0.65 \mathrm{mM}$ NADP (Sigma); $0.24 \mathrm{mM}$ nitrotetrazolium blue (Wako Junyaku, Japan). The oocytes, embryos or separated blastomeres from each embryo were washed three times with the reaction mixture and transferred to a fresh reaction mixture in drops on a microtest plate, Terasaki (Nunc). The reaction was carried out at $39^{\circ} \mathrm{C}$ for $60 \mathrm{~min}$ and then the oocytes, embryos or blastomeres were classified in four levels (strong, moderate, weak and negative activity) depending on the degree of stain intensity. The activity of demi-embryos was represented as an averaged score of all blastomeres from each separated embryo, because there was a variance in the degree of stain intensity of blastomeres from one embryo.

\section{Chromosome preparation and analysis}

Blastomeres were processed and chromosomes were prepared by the method described in the previous papers (Iwasaki et al., 1988, 1989a) with minor modification in pronase treatment and fixation. Briefly, the blastomeres were cultured in TCM 199 medium containing vinblastin and podophyllotoxin for 8-12 hr to arrest the cleavage division at metaphase. They were then placed in hypotonic solution $(0.9 \%$ sodium citrate) for 30 min without treatment with pronase. The first and second fixations were made by transferring the blastomeres to fixative solutions consisting of acetic acid, methanol and hypotonic solution (5:15:8), and acetic acid and methanol (1:3), respectively. Chromosomes were counted and the sex chromosomes were determined after staining with Giemsa.

Comparisons of the intensity of G-6-PDH activities in female and male embryos were made by chi-square test. 

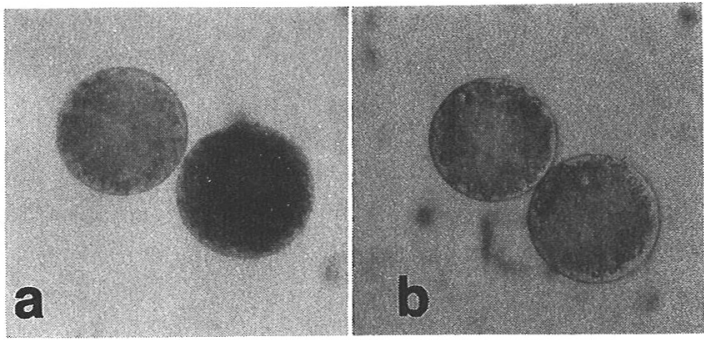

Fig. 1. Histochemical detection of glucose-6phosphate dehydrogenase activity of bovine demi-embryo at four-cell stage. a: Right blastomere stained dark blue color showing the presence of activity. b: Control reacted without substrate.

\section{Results}

Diformazan granules were spread throughout the cytoplasm of bovine oocytes or embryos under reaction with the substrate mixture for G-6-PDH but not detected in reactions with substrate-free mixture (Fig. 1).

Changes in G-6-PDH activity in matured and fertilized bovine oocytes and in embryos with development are shown in Table 1. There was no definite tendency in G-6-PDH activity from matured oocytes to the eight-cell stage although there was no activity at morulae stage. Accordingly, sex differences in G-6-PDH activity of embryos were investigated from the two- to eightcell stages.

Sexing rates of blastomeres separated from embryos are shown in Table 2. Total 198 $(53.5 \%)$ of 370 embryos and $272(43.1 \%)$ of 631 blastomeres produced one or more metaphase spreads. A total of 116 embryos were successfully karyotyped and the rates were $58.6 \%$ for analyzed embryos and $31.4 \%$ for processed embryos.

Because of no difference in G-6-PDH activity between two experiments, the combined data for activity in normal diploid female and male embryos are shown in Table 3. In both female and male embryos, they showed a diversity in the intensity of G-6-PDH activities at each stage. There was no significant sex difference in the G-6-PDH activities, although the male embryos showed a higher rate $(25.5 \%)$ in the strong intensity than that in female embryos $(7.7 \%)$.

G-6-PDH activity in embryos karyotyped was clarified according to the number of X-choromsomes and summarized in Table 4. There was no definite tendency in the intensity of G-6-PDH

Table 1. Changes in G-6-PDH activity of bovine oocytes and embryos with development

\begin{tabular}{|c|c|c|c|c|c|c|c|}
\hline \multirow{2}{*}{$\begin{array}{l}\text { G-6-PDH } \\
\text { activity }\end{array}$} & \multicolumn{3}{|c|}{ No. of oocytes } & \multicolumn{4}{|c|}{ No. of embryos } \\
\hline & Matu. ${ }^{\mathrm{a}}$ & Penet. ${ }^{b}$ & $\mathrm{PN}^{\mathrm{c}}$ & 2-cell & 4-cell & 8-cell & Morulae \\
\hline Strong & 6 & 1 & 5 & 4 & 1 & 0 & 0 \\
\hline Moderate & 3 & 1 & 0 & 3 & 7 & 1 & 0 \\
\hline Weak & 2 & 0 & 0 & 2 & 1 & 4 & 0 \\
\hline Negative & 0 & 4 & 2 & 1 & 6 & 5 & 4 \\
\hline
\end{tabular}

a: Matured oocyte, b: Sperm penetrated egg, c: Pronuclei stage.

Table 2. Sexing rate for blastomeres separated from bovine embryos

\begin{tabular}{|c|c|c|c|c|c|c|c|c|c|}
\hline \multirow{2}{*}{$\begin{array}{l}\text { Stage } \\
(- \text { cell })\end{array}$} & \multicolumn{2}{|c|}{ No. processed } & \multicolumn{2}{|c|}{ No. analyzed } & \multirow{2}{*}{$\begin{array}{l}\mathrm{C} / \mathrm{A} \\
(\%)\end{array}$} & \multirow{2}{*}{$\begin{array}{c}\mathrm{D} / \mathrm{B} \\
(\%)\end{array}$} & \multirow{2}{*}{$\begin{array}{l}\text { Karyo- } \\
\text { typed } \\
\text { embryos } \\
(\mathbf{E})\end{array}$} & \multirow{2}{*}{$\begin{array}{l}\mathrm{E} / \mathrm{A} \\
(\%)\end{array}$} & \multirow{2}{*}{$\begin{array}{l}\mathrm{E} / \mathrm{C} \\
(\%)\end{array}$} \\
\hline & $\begin{array}{c}\text { Embryos } \\
\text { (A) }\end{array}$ & $\begin{array}{l}\text { Blasto- } \\
\text { meres (B) }\end{array}$ & $\begin{array}{c}\text { Embryos } \\
\text { (C) }\end{array}$ & $\begin{array}{l}\text { Blasto- } \\
\text { meres (D) }\end{array}$ & & & & & \\
\hline 2 & 61 & 61 & 23 & 23 & 37.7 & 37.7 & 14 & 23.0 & 60.9 \\
\hline 3 & 84 & 128 & 53 & 70 & 63.1 & 54.7 & 35 & 41.7 & 66.0 \\
\hline 4 & 140 & 234 & 86 & 123 & 61.4 & 52.6 & 48 & 34.3 & 55.8 \\
\hline $5-7$ & 73 & 174 & 32 & 48 & 43.8 & 27.6 & 17 & 23.3 & 53.1 \\
\hline 8 & 12 & 34 & 4 & 8 & 33.3 & 23.5 & 2 & 16.7 & 50.0 \\
\hline Total & 370 & 631 & 198 & 272 & 53.5 & 43.1 & 116 & $31 \cdot 4$ & 58.6 \\
\hline
\end{tabular}


Table 3. G-6-PIDH activity in normal female and male diploid embryos

\begin{tabular}{lccccc} 
& \multicolumn{5}{c}{ G-6-PDH activity } \\
\cline { 2 - 6 } Sex & Strong & Moderate & Weak & Negative & Total \\
\hline Female & $3(7.7)^{*}$ & $7(17.9)$ & $8(20.5)$ & $21(53.8)$ & 39 \\
Male & $13(25.5)$ & $7(13.7)$ & $6(11.8)$ & $25(49.0)$ & 51 \\
\hline
\end{tabular}

*No. of embrys ( $\%$ of total embryos).

Table 4. G-6-PDH activity in bovine embryos according to X-chromosome dosage

\begin{tabular}{|c|c|c|c|c|c|c|}
\hline \multirow{2}{*}{$\begin{array}{c}\text { No. of } \\
\text { X-chromosome }\end{array}$} & \multirow{2}{*}{$\begin{array}{c}\text { Chromosome } \\
\text { complement }\end{array}$} & \multirow{2}{*}{$\begin{array}{l}\text { No. of } \\
\text { embryos }\end{array}$} & \multicolumn{4}{|c|}{ G-6-PDH activity } \\
\hline & & & Strong & Moderate & Weak & Negative \\
\hline \multirow[t]{3}{*}{1} & $\mathrm{x}$ & 3 & 0 & 2 & 0 & 1 \\
\hline & XY & 51 & 19 & 7 & 6 & 25 \\
\hline & XYY & 2 & 0 & 1 & 0 & 1 \\
\hline \multirow[t]{3}{*}{2} & $\mathrm{XX}$ & 39 & 3 & 7 & 8 & 21 \\
\hline & $\mathrm{XXY}$ & 4 & 0 & 1 & 2 & 0 \\
\hline & XXYY & 3 & 0 & 0 & 0 & 3 \\
\hline 3 & $\mathrm{XXX}$ & 5 & 1 & 1 & 1 & 2 \\
\hline 4 & $\mathrm{XXXX}$ & 6 & 2 & 0 & 0 & 4 \\
\hline 6 & $\mathrm{XXXXXX}$ & 1 & 1 & 0 & 0 & 0 \\
\hline
\end{tabular}

activity, although some of embryos with three to six X-chromosomes showed the strong intensity in G-6-PDH activities.

\section{Discussion}

Brinster (1966) determined G-6-PDH activity in preimplantation mouse embryos using the spectrophotometric method. This method is not to apply to bovine embryo because the presence of numerous lipid granules in the cytoplasm causes difficulty in denaturing bovine embryos only by freeze-thawing or ultrasound treatment. Consequently, G-6-PDH activity of individual bovine embryos was assayed using the histochemical method.

Histochemical study revealed that G-6-PDH activity in bovine embryos decreased from the eight-cell stage to the early morulae (Table 1). These results were coincident with those of mouse embryos (Brinster, 1966). Crosby et al. (1988) found that the full activation of transcription in sheep embryos occurs in the 4th cell cycle. But there has been no report as for the expression of the embryonic genome in bovine embryos. Consequently, sex difference in G-6-PDH activity was investigated at the two- to eight-cell stage in this study.
The reaction of blastomeres to G-6-PDH substrate mixture was not uniform. Consequently, G-6-PDH activity was represented by an averaged score of all blastomeres obtained by separation from each individual embryos. This phenomenon has also been observed in the mouse embryo (Niimura, personal communication). It is not clear whether the difference of activity in individual blastomere is caused by difference of developmental ability.

Sexing rate for the analyzed embryos was about $59 \%$ in Exp. 1 (Table 2) and this rate was almost the same as the result reported in a previous paper (Iwasaki et al., 1989b).

G-6-PDH activity in normal diploid male embryos was slightly higher than that in female, but there was no significant difference between the sexes of bovine embryos at the two- to eight-cell stage. These facts show that the embryonic gene for G-6-PDH has not been expressed. In the mouse, Williams (1986) demonstrated successful sexing by a visual colorimetric assay of G-6-PDH activities at the eight-cell stage. However, the experiments using spectrophotometric method failed to demonstrate $\mathrm{X}$ bimodal distribution for G-6-PDH in the pre-implantation stage (Brinster, 1970; Leese, 1987). But the cause of this discrepancy is not clear. In bovine embryos, it has 
not been shown when an embryonic gene was expressed although the full activation of transcription in sheep embryos occurs in the 4th cell cycle (Crosby et al., 1988) as described above. It needs to clarify the stage of the expression of embryonic genes.

In mouse embryos, high activities are shown in $\alpha$-Gal or HGPRT which are linked with Xchromosome after the eight-cell stage (Adler et al., 1977; Monk and Harper, 1978). However, the genetic dosage effect of the $\mathrm{X}$-chromosomes is not present in the late morulae and the blastocyst stages which show the high HGPRT activity (Monk and Harper, 1978). Consequently, at first, it needs to clarify the developmental changes in $\alpha$-Gal and HGPRT activities in bovine embryos.

A high activity was observed in some embryos with three or more X-chromosomes. But because the number of these embryos was so low, we shall have to investigate the relationship between $G$ 6-PDH activity and polyploidy using polyploid embryos produced by electrofusion (Iwasaki et al., in press).

In conclusion, histochemical measurements did not clarify sex differences in G-6-PDH activity in bovine embryos in the present study.

\section{Acknowledgments}

The authors wish to thank Dr. Sueo Niimura, Faculty of Agriculture, Niigata University for helpful advice on the histochemical analysis of glucose-6-phosphate dehydrogenase activity of bovine oocytes and embryos. This study was partly supported by grant No. 63-1926 from the Ministry of Agriculture, Forestry and Fisheries.

\section{References}

Adler DA, West, JD, Chapman VM (1977) Expression of $\alpha$-galactosidase in preimplantation mouse embryos. Nature 267: 838-839.

Brinster R (1966) Glucose 6-phosphate dehydrogenase activity in the preimplantation mouse embryo. Biochem J 101: 161-163.

Brinster R (1970) Glucose 6-phosphate dehydrogenase activity in the early rabbit and mouse embryo. Biochem Genet 4: 669-676.

Chapman VM, Shows TB (1976) Somatic cell genetic evidence for X-chromosome linkage of three enzymes in the mouse. Nature 259: 665-667.

Crosby IM, Gandolfi F, Moor RM (1988) Control of protein synthesis during early cleavage of sheep embryos. J Reprod Fert 82: 769-775.

Epstein CJ, Smith S, Travis B, Tucker G (1978) Both $\mathrm{X}$-chromosomes function before visible X-chromosome inactivation in female mouse embryos. Nature 274: 500-503.

Iwasaki S, Shioya Y, Hanada A, Nakahara T (1988) Chromosome preparation from 2-cell bovine embryos derived from follicular oocytes fertilized in vitro. Jpn J Anim Reprod 34: 79-83.

Iwasaki S, Shioya Y, Masuda H, Hanada A, Nakahara $T$ (1989a) Incidence of chromosomal anomalies in early bovine embryos derived from in ritro fertilization. Gamete Res 22: 83-92.

Iwasaki S, Kono T, Nakahara T (1989b) Sexing rate and developmental ability of bovine two- to eightcell embryos split by treatment with pronase. Jpn J Anim Reprod 35: 147-153.

Iwasaki S, Kono T, Fukatsu H, Nakahara T Production of bovine tetraploid embryos by electrofusion and their developmental capability in vitro. Gamete Res (in press).

Kozak LP, Quinn PJ (1975) Evidence for dosage compensation of an X-linked gene in the 6-day embryo of the mouse. Develop Biol 45: 65-73.

Leese HJ (1987) Non-invasive methods for assessing embryos. Human Reprod 2: 435-438.

Lyon MF (1961) Gene action in the X-chromosome of the mouse (Mus musculus I..). Nalure 190: $372-373$.

Monk M (1978) Biochemical studies on X-chromosome activity in preimplantation mouse embryos. In: Genetic Mosaics and Chimeras in Mammals (Russell LB ed), Plenum Press, New York. pp 239-246.

Monk M, Harper M (1978) X-chromosome activity in preimplantation mouse embryos from XX and XO mothers. J Embryol Exp Morph 46: 53-64.

Monk M, Handyside $H$ (1988) Sexing of preimplantation mouse embryos by measurement of X-linked gene dosage in a single blastomere. $J$ Reprod Ferl 82: $365-368$.

Niimura S, Ishida K (1977) Histochemical studies of glucose-6-phosphate dehydrogenase in hamster and pig eggs. Jpn J Anim Reprod 23: 72-75.

Shimizu N, Shimizu Y, Kondo I, Woods C, Wegner T (1981) The bovine genes for phosphoglycerate kinase, glucose-6-phosphate dehydrogenase, alphagalactosidase, and hypoxanthinc phosphoribosyltransferase are linked to the $\mathrm{X}$-chromosome in cattle-mouse hybrids. Cytogenet Cell Genet 29: 26-31.

Takagi N (1974) Differentiation of X chromosomes in early female mouse embryos. Exp Cell Res 86: $127-135$.

Williams TJ (1986) A technique for sexing mouse 
embryos by a visual colorimetric assay of the $\mathrm{X}$ linked enzyme, glucsoe-6-phosphate dehydrogenase.

Theriogenology 25: 733-739.

\title{
牛卵子および初期胚におけるグルコース 6 リン酸 脱水素酵素活性の発生に伴う变動と性差
}

\author{
岩崎 説雄・塩谷 康生**門司 恭典 ** $^{*}$-中原 详夫

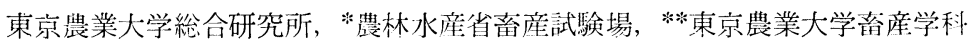

\footnotetext{
牛卵胞卵子の体外成然抢上び体外受精, ならびに胚の 発生過程に伴うグル ルース 6 リン酸脱 水酵素 (G-6-

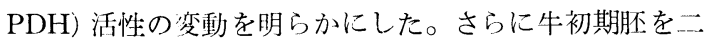
分し, 分離胚の一力で G-6-PDH 活性を組織化学的に測 定し，他方で染色体検査により性判別を行い，活性の性 差を調べ，酵素活性の差を利用した泼の性制御の可能性 を検討した。

胚の性差の検討においては，実験 1 ではランダムに卵 单より卵胞卵在採取し, 実験 2 では卵胞卵を多数有する 卵巣より卵巣別に卵子を採取して, 体外成熟, 体外受精 に供した。G-6-PDH 活性は組織化学的に測定し, 染色 強度により強, 中, 弱, 不染の 4 スコアに区分して表し た。

G-6-PDH 活性江成熟卵子, 前核期卵子から 8 細胞期
}

にかけて大きな変化は認められなかったが，桑実期では 活性を示さなかった。370 個の肧より分離した 631 個の 割球を染色体検查に供し，このうち 116 個（分裂中期核 板像を示した胚の $58.6 \%$ ）の胚で核型が判別した。これ らのうち正常 2 倍体の雌胚39個の G-6-PDH 活性は, 雄 胚51個の活性に比べやや低いが有意差は認められなかっ た。染色体異常を含め, X染色体の数に上り分類した G-6-PDH 活性は一定の傾向はみられなかったが，多倍 体肧（XXX，XXXX，XXXXXX) のいくつかは高い活 性を亦すことが認为られた。

以上の成績上り，牛初期胚 G-6-PDH 活性の性差は明 確ではないが，多倍体肧のいくつかは高い活性を示すこ とが認められた。 